\title{
EFFECT OF PERCEPTION ON SHARIA BANKS AND VARIETY SEEKING ON CUSTOMER SWITCHING INTENTION FROM CONVENTIONAL BANKS TO SHARIA BANKS IN BEKASI CITY
}

\author{
Estu Banyu Ramadhani ${ }^{1}$, Adril Hakim², Rianti Pratiwi ${ }^{3}$
}

${ }^{1}$ SEBI: Email: estubanyur@gmail.com

${ }^{2}$ SEBI Lecturer \& Doctoral Candidate UIN Syarif Hidayatullah Email : adrh272@yahoo.com

${ }^{3}$ SEBI Lecturer \& Doctoral Candidate RMIT University Email:: rianti.affandi@gmail.com

\begin{abstract}
As known, the competition between banks in Indonesia is increasingly tight. Making each bank in various ways such as developing products, improving services, procuring promos, etc., continues to be carried out to get potential customers for the continuity of their business. Only banks are able to attract new consumers and retain old consumers who may be able to grow and develop for long periods of time. Therefore, it becomes a challenge for sharia bank marketers in creating marketing strategies in accordance with Islamic law. In this case, one of the things that can be done by Islamic bank marketers is to approach the community by identifying whether or not there are customers of conventional banks who want to move to Islamic banks. This study aims to determine the effect of customer perceptions of Islamic banks and variety seeking on the customer intention to switch from conventional banks to Islamic banks. Data collection techniques in this study were conducted by distributing questionnaires to all Muslim society in Bekasi City. Sampling is done by judgmental sampling technique so that it gets 101 samples. The research method used is quantitative associative research and data is processed using Partial Least Square (PLS). The results of this study indicate that only variable perception society about the bank sharia who influential significant effect on the customer intention to switch from conventional banks to Islamic banks, while variety seeking does not have a significant effect on the customer intention to switch from conventional banks to Islamic banks.
\end{abstract}

Keywords: Customer Switching Intention, Customer Perception, Variety Seeking

\section{INTRODUCTION}

At the beginning of its emergence, the existence of Islamic banks had not received much attention because the Indonesian people were accustomed to the system used by conventional banks. Thus, banks with the Islamic system have not been much apprehended by the public. Over time, after the monetary crisis that occurred from 1997 to 1998, finally, Islamic banks began to show their existence to the public. The high-interest rate during the monetary crisis resulted in the conventional banks experiencing negative spreads, causing a decrease in public confidence in conventional banking (Masruroh, 1999). As a result, with the high-interest rate at that time, many conventional banks were liquidated. At the same time, Islamic banking, which came with the profit-sharing principle, was able to prove its ability to remain stable amid the monetary crisis. 
6 | Estu Banyu Ramadhani, Adril Hakim, Rianti Pratiwi: Effect of Perfection on Sharia Bank and Variety Seeking on Customer Switching Invention From Conventional Banks in Bekasi City

As one of the countries with the largest Muslim population, Indonesia has great potential to become a center for the development of the Islamic financial industry in the world. Based on BPS (2010) it shows that 207,176,162 of 237,641,326 Indonesians are Muslim. This population means that there is potential for Islamic banks to grow by attracting people to become customers of $87.18 \%$ of the Indonesian population.

Indonesia is also included in the top ten countries that have the most extensive Islamic financial index in the world. Based on the 2017 Global Islamic Financial Report (GIFR) shows that Indonesia ranks the seventh country that has the potential in developing the Islamic financial industry after Kuwait, and Pakistan. Some of the factors that influence in calculating this index are the number of Islamic banks, the number of Islamic non-bank financial institutions, Islamic supervisory bodies under the government, the size of Islamic financial assets, Muslim population, cultural-education, outstanding Sukuk, and Islamic laws and regulations in the country (IFCI, 2017).

Seeing the potential of Islamic banks provides information that the market share of Islamic banks in Indonesia should be high. However, the market share owned by Islamic banks is still quite low. In 2018 the Islamic Bank market share reached $5.96 \%$ of the total national banking industry (OJK, 2018). This potential is different from the conventional bank market share is higher, at $94.04 \%$. If seen from the number of savings accounts, Islamic Banks are still quite low, as of December 2018 amounting to 24,067,983 (OJK, 2019) accounts of the total number of savings accounts at commercial banks in Indonesia, amounting to 275,764,037 (LPS, 2019). This fact suggests that there are still many Muslim communities who have not used Islamic banks as an alternative in fulfilling their transactions.

As is known, the competition that occurs between banks in Indonesia is increasingly tight. Making each bank in various ways, such as product development, service improvement, procurement promos, continues to be done to get potential customers for the sustainability of their business. Only banks can attract new customers and retain old customers who may be able to grow and develop for a long time. Therefore, it becomes a challenge for Islamic bank marketers to create marketing strategies following Islamic law. In this case, one of the things that can be done by Islamic bank marketers is to approach the public by identifying whether or not there are conventional bank customers who want to move to Islamic banks. According to Suwarsi and Wulandari (2017) in his research found factors that cause customer switching intention behavior are extrinsic factors including; sales promotion, and brand quality, and intrinsic factors include; variety seeking, consumer loyalty, consumer perception, consumer preferences, attitudes, consumer knowledge, service quality, and religiosity. Other research conducted by Najib (2009) in his research found that the factors that had the most significant influence on consumers in switching were internal factors, including; bored with old products, curiosity, security, and a sense of value. This research will focus on the variety-seeking variable and people's perceptions that influence the intention to move customers. 
Jurnal Ekonomi dan Perbankan Syariah

Vol. 7. No.2, 0ktober 2019: 5-19, ISSN (cet): 2355-1755 | ISSN (online): 2579-6437

\section{7}

As one of the cities that supports the activities of the Capital City of Jakarta, Bekasi City is one of the cities that has very rapid economic development. In this case, the Financial Services and Insurance sectors made a significant contribution to the economy of Bekasi City. It can be seen in 2018 that Financial Services and Insurance contribute $3.11 \%$ of the total Gross Regional Domestic Product (GRDP) of Bekasi City (BPS, 2019). This data shows that many people in Bekasi City have a bank account to assist in their transactions. Therefore, as one of the cities that has a sizeable Muslim population of 2,141,407 (BPS, 2016), Bekasi City has the potential to develop the Islamic banking market in Indonesia.

Based on this background, the formulation of the problem in this research is formed: Does the perception of Sharia Banks and variety-seeking affect the intention of moving Conventional Bank customers to Islamic Banks in the Muslim community in Bekasi City? This fact is to determine the effect of perceptions regarding Islamic banks and variety-seeking on the intention of moving conventional bank customers to Islamic banks in the Muslim community of Bekasi City.

\section{LITERATURE REVIEW \\ 2.1. Perception Regarding Sharia Banks}

According to Hawkins \& Mothersbaugh (2016, p. 274), perception is a process that starts with the exposure and attention from consumers on marketing stimuli, which end with consumer interpretation (interpretation). Kotler \& Keller (2012, p. 268) define brands as names, terms, signs, symbols, designs, or combinations of these elements that are intended to identify goods and services from one seller or group of sellers and to distinguish them from their competitors. According to Keller (2013, hlm. 44), brand perception is a consumer perception about a brand as reflected by brand associations that exist in consumers' memories.

Keller (2013, p. 50) mentioned that the measurement of brand perception (brand image) could be done based on several aspects, namely:

1) Strength of brand associations, including the depth of someone thinking about information about a product and connecting it with existing brand knowledge, as well as signs or cues that make a person consider a brand.

2) Favorability of brand associations, namely brand associations that depend on the situation or context, and its nature varies according to what consumers want to achieve in a purchasing decision.

3) The uniqueness of brand associations, namely the existence of excellence and unique impression on the brand that gives consumers a strong reason why they should choose it. 
8 | Estu Banyu Ramadhani, Adril Hakim, Rianti Pratiwi: Effect of Perfection on Sharia Bank and Variety Seeking on Customer Switching Invention From Conventional Banks in Bekasi City

\subsection{Variety Seeking}

Menurut Mowen dan Minor (2012, hlm. 133) variety seeking atau mencari keragaman mengacu kepada kecenderungan konsumen untuk mencari secara spontan membeli baru meskipun mereka terus mengungkapkan kepuasan mereka dengan merek yang lama. Variety seeking merupakan suatu perilaku pembelian dimana tingkat keterlibatan konsumen yang rendah, sedangkan terdapat banyak perbedaan merek yang signifikan dihadapannya (Assael, 2001).

Variety seeking merupakan komitmen kognitif untuk membeli merek yang berbeda karena faktor-faktor seperti stimulasi yang terlibat dalam mencoba berbagai merek, rasa ingin tahu sesuatu hal yang baru, atau sesuatu hal yang dapat mengatasi kebosanan dengan hal lama yang sama (Peter \& Olson, 2010, hlm. 390).

\subsection{Customer Switching Intention}

According to Zhang (2009), customer switching can be interpreted as a decision made by a customer to stop the purchase or subscription of company services completely, and if in banking, customer transfer means a transfer made by a customer from one bank to another. Displacement of customers is the result of customer dissatisfaction with a product that causes customers to stop buying products on a brand and replace it with another brand (Hawkins \& Mothersbaugh, 2016, p. 637).

Bansal et al., (2005) explains that switching intentions as a level of likelihood or certainty that customers will move from current service providers to new service providers (Harianja et al., 2017). According to Ajzen (2005), Theory of planned behavior assumes that humans act rationally, they will take into account available information, either implicitly or explicitly, and they will consider the consequences of the actions they take. The intention or intention of someone to take action is guided by three kinds of considerations, namely: (1) beliefs about the consequences of behavior (behavioral beliefs); (2) beliefs derived from the normative expectations of others and motivation to comply with these expectations (normative beliefs), and (3) beliefs about the existence of factors that can facilitate or hinder the performance of behavior and the resulting strength (control beliefs) (Ajzen, 2005).

Furthermore, when each belief is put together, behavioral beliefs produce attitudes toward the behavior, normative beliefs produce subjective norms, and control beliefs produce perceived behavior control. When combined between attitudes toward behavior, subjective norms, and behavioral control, it forms behavioral intentions. The higher the construct, the more significant the realization of that intention when there is an opportunity. 


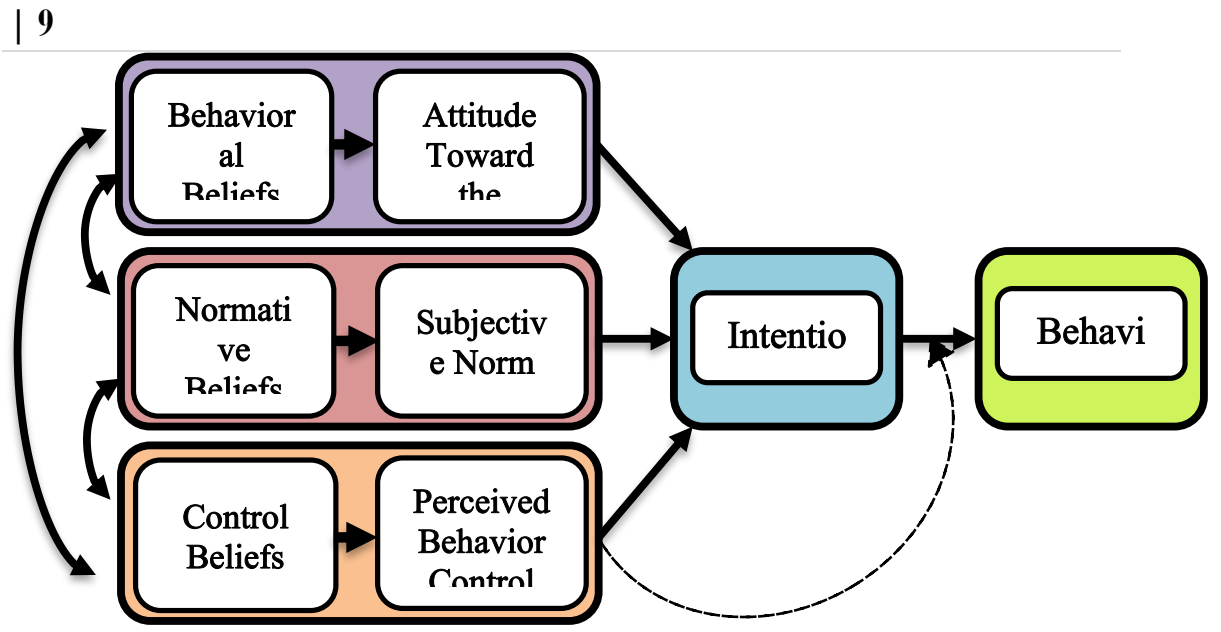

Figure 1 Theory of Planned Behavior

Source: Ajzen (2005)

\subsection{Conceptual Framework}

Berdasarkan teori yang telah disampaikan sebelumnya, untuk mengetahui pengaruh persepsi masyarakat mengenai bank syariah dan variety seeking terhadap niat perpindahan nasabah bank konvensional ke bank syariah, maka dibuatlah kerangka penelitian sebagai berikut.

Figure 2 Conceptual Framework

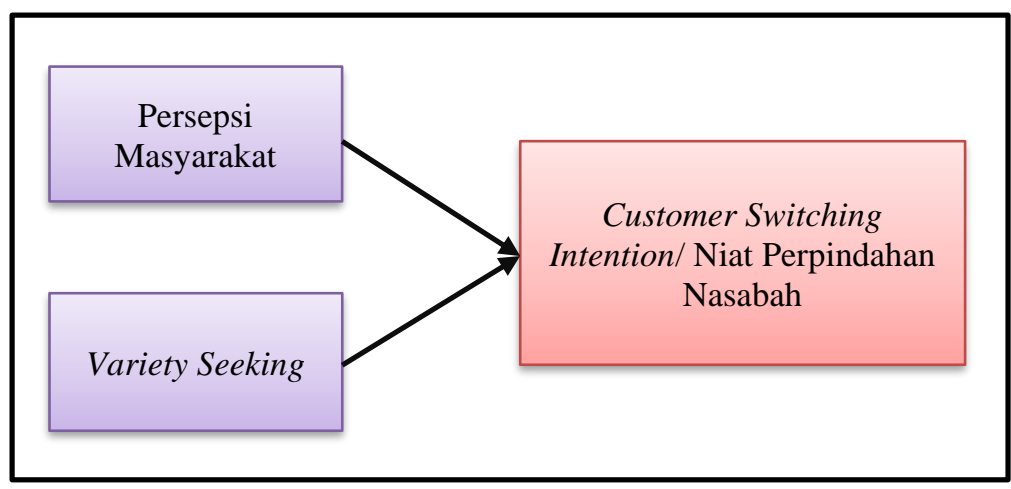

Source: data processed, 2019

\section{RESEARCH METHODOLOGY}

This research is a quantitative study. Data sources used in this study are primary data obtained through questionnaires and interviews. The population in 
10 | Estu Banyu Ramadhani, Adril Hakim, Rianti Pratiwi: Effect of Perfection on Sharia Bank and Variety Seeking on Customer Switching Invention From Conventional Banks in Bekasi City

this study were all Muslim communities in Bekasi City. The sampling technique uses a judgmental sampling technique. In determining the number of samples from the population, this study refers to the statement of Hair et al. (2010) that the number of samples used as respondents in the study must be adjusted to the number of indicators used in the questionnaire, assuming $\mathrm{n} \times 5$ observed variables (indicators) up to $\mathrm{n} x 10$ observe the variable (indicator). In this case, the study obtained a sample of 101 people.

The variables in this study consisted of the independent variable and the dependent variable. The independent variable of this study is the perception of Islamic banks and variety seeking, while the dependent variable in this study is the intention to move customers. The measurement of each variable is carried out using the indicator variables as follows.

Table 1 Operationalization of Research Variables

\begin{tabular}{|c|c|c|c|c|}
\hline Variable & Indicators & No. Item & Scale & $\begin{array}{c}\text { Measurem } \\
\text { ent }\end{array}$ \\
\hline \multicolumn{5}{|c|}{ Independent Variables } \\
\hline \multirow{3}{*}{$\begin{array}{l}\text { Percetion } \\
\text { of Sharia } \\
\text { Banks } \\
\text { (Keller, } \\
\text { 2013) }\end{array}$} & $\begin{array}{l}\text { - Strength of brand } \\
\text { associations }\end{array}$ & $\mathrm{X} 1.1 \& \mathrm{X} 1.2$ & \multirow[t]{3}{*}{$\begin{array}{l}\text { Interv } \\
\text { al }\end{array}$} & \multirow{3}{*}{$\begin{array}{l}\text { 5-point } \\
\text { Likert } \\
\text { Scale }\end{array}$} \\
\hline & $\begin{array}{l}\text { - Favorability of brand } \\
\text { associations }\end{array}$ & $\mathrm{X} 1.3 \& \mathrm{X} 1.4$ & & \\
\hline & $\begin{array}{l}\text { - Uniqueness of brand } \\
\text { associations. }\end{array}$ & $\mathrm{X} 1.5 \& \mathrm{X} 1.6$ & & \\
\hline \multirow{3}{*}{$\begin{array}{l}\text { Variety } \\
\text { Seeking } \\
\text { (Peter \& } \\
\text { Olson, } \\
\text { 2010) }\end{array}$} & - Rasa ingin tahu Curiosity & $\mathrm{X} 2.1$ & \multirow{3}{*}{$\begin{array}{l}\text { Interv } \\
\text { al }\end{array}$} & \multirow{3}{*}{$\begin{array}{l}\text { 5-point } \\
\text { Likert } \\
\text { Scale }\end{array}$} \\
\hline & $\begin{array}{l}\text { - Interested in trying other } \\
\text { brands }\end{array}$ & $\mathrm{X} 2.2$ & & \\
\hline & - Boredom & $\mathrm{X} 2.3$ & & \\
\hline \multicolumn{5}{|c|}{ Dependent Variables } \\
\hline \multirow{3}{*}{$\begin{array}{l}\text { Customer } \\
\text { Switching } \\
\text { Intention } \\
\text { (Ajzen, } \\
2005 \text { ) }\end{array}$} & - behavioral beliefs) & Y.1 \& Y.2 & \multirow{3}{*}{$\begin{array}{l}\text { Interv } \\
\text { al }\end{array}$} & \multirow{3}{*}{$\begin{array}{l}\text { 5-point } \\
\text { Likert } \\
\text { Scale }\end{array}$} \\
\hline & - normative beliefs & Y.3 \& Y.4 & & \\
\hline & - control beliefs & Y.5 \& Y.6 & & \\
\hline
\end{tabular}

Source: Data processed, 2019

Data analysis was performed with descriptive analysis and Partial Least Structural (PLS) Structural Equation Modeling (SEM). Descriptive analysis in this study describes the characteristics of respondents and knows the responses of questions that have been given previously in the questionnaire. Meanwhile, PLS-SEM is used to determine the causality relationship between latent variables that are formed (perceptual variables regarding sharia banks and variety-seeking variables on customer movement intention variables) 
Jurnal Ekonomi dan Perbankan Syariah

Vol. 7. No.2, 0ktober 2019: 5-19, ISSN (cet): 2355-1755 | ISSN (online): 2579-6437

\section{1}

\section{ANALYSIS AND DISCUSSION}

\subsection{Profile of Respondents}

Based on gender from 101 selected respondents, 68 were female respondents and 33 male respondents. Based on age, aged 21-30 years as many as 53 people, $31-40$ years as many as 20 people, $\leq 20$ years as many as 14 people, 41-50 years as many as 12 people, and the rest were respondents aged over 51 years as many as two people. Based on the most recent education, 54 people had the last high school; after that, it was followed by respondents who had 32 Bachelor, 13 from Diploma one from the master's degree, and one from elementary school. Based on the work of respondents as students, 42 people, 30 private employees, 14 homemakers, five entrepreneurs, 5 lecturers/academics/teachers, two civil servants, one job seeker, entrepreneur, and the last is one nurse.

Based on the products and services that are widely used by respondents are savings, then followed by transfers, deposits, credit cards, consumer credit, and term savings, while it is known that respondents do not use other products, such as current accounts and working capital loans in this study. From the results of the distribution of the questionnaire, it was found that the dominance of respondents knew of Islamic banks from the Internet, Friends, and Family / Siblings. After that, it is followed by information from the teacher/lecturer, magazines, figures/experts, Instagram, TV ads, Media Information, Neighbors, and News. Based on sharia bank account ownership of 101 respondents, 37 people already have sharia bank accounts, while the remaining 64 people do not have sharia bank accounts.

\subsection{PLS-SEM Results}

\subsubsection{Outer Model Test}

The measurement model is a model that describes the relationship between indicator blocks and their latent variables. Where the measurement model is used to test the construct validity and instrument reliability, the evaluation of the measurement model carried out in this study can be seen as follows.

\section{Convergent Validity}

Based on the results of the study in the first validity test, it can be seen that several indicators have a loading factor value below 0.6 . The indicator is boredom (X2.3). Therefore, indicators with loading factor values below 0.6 are removed from the model and then retested. After repeated testing, the results obtained by loading factor values on all indicators above 0.6. Therefore, it can be concluded that all research indicators are valid. 
12 | Estu Banyu Ramadhani, Adril Hakim, Rianti Pratiwi: Effect of Perfection on Sharia Bank and Variety Seeking on Customer Switching Invention From Conventional Banks in Bekasi City

\section{Discriminant Validity}

After convergent validity, the next evaluation is to see the results of discriminant validity. Discriminant validity has the principle that meters of different constructs should not be highly correlated. Based on the results of the study, it can be seen that the construct model value has a higher correlation with the indicator than with the indicators on the other block constructs. Thus, the indicators for each construct in this study already meet discriminant validity.

Also, another method that can be used for discriminant validity is by comparing the AVE root values with correlations between constructs. In this case, if the root AVE for each construct is higher than the correlation between constructs with other constructs in the model, then the discriminant validity can be said to be good. Based on the results of this study, it can be seen that the root value of each construct is higher than the correlation between constructs with other constructs, so it can be concluded that the measurements in this study have good discriminant validity. The results can be known in the following tables.

Table 2 Average Variance Extracted (AVE)

\begin{tabular}{|c|c|c|}
\hline & $\begin{array}{c}\text { Average Variance Extracted } \\
(\mathrm{AVE})\end{array}$ & Akar AVE \\
\hline Customer Switching Intention & 0.620 & 0.787 \\
\hline $\begin{array}{c}\text { Persepsi mengenai Bank } \\
\text { Syariah }\end{array}$ & 0.612 & 0.782 \\
\hline Variety Seeking & 0.723 & 0.850 \\
\hline
\end{tabular}

Sumber: Data diolah, 2019

\section{Reliability Test}

As for PLS, reliability testing can be applied by two methods, namely Cronbach's Alpha and Composite Reliability. In this case, the value of Cronbach's alpha and composite reliability has the same rule of thumb, ie, the value must be more than 0.6 .

Based on the results of the study can be seen the value of Cronbach's Alpha on the variable customer switching intention of 0.878 , the perception variable about Islamic banks at 0.874 , and the variety-seeking variable at 0.622 . This value shows that the measurements in this study are reliable because each variable has an alpha value $>0.6$. Also, it can be seen that the value of Composite Reliability of each construct in this study is declared reliable, which can be seen from the Composite Reliability value of each construct, which is above 0.6. Thus, the model can proceed to the next stage, namely testing the structural model (inner model). The output of Cronbach's alpha and composite reliability in this study can be seen as follows. 
Jurnal Ekonomi dan Perbankan Syariah

Vol. 7. No.2, 0ktober 2019: 5-19, ISSN (cet): 2355-1755 | ISSN (online): 2579-6437

13

Table 3 Output Cronbach's Alpha dan Composite Reliability

\begin{tabular}{|c|c|c|}
\hline & $\begin{array}{c}\text { Cronbach's } \\
\text { Alpha }\end{array}$ & Composite Reliability \\
\hline Customer Switching Intention & 0.878 & 0.907 \\
\hline Perception of Sharia Banks & 0.874 & 0.904 \\
\hline Variety-Seeking & 0.622 & 0.839 \\
\hline
\end{tabular}

Sumber: Data diolah, 2019.

\subsubsection{Inner Model Test}

After evaluating the measurement model, the next step is evaluating the structural model. Structural model testing is done to predict the causality relationship between latent variables through $\mathrm{R}$-Square values and path coefficients. By looking at the value of R-Square, it can be seen the level of variation in the change of the dependent variable that can be explained by the independent variable. Meanwhile, looking at the value of the path coefficient can indicate the level of significance in hypothesis testing. The results of testing the structural model in this study can be seen as follows.

\section{Determination Coefficient (R-Square)}

Based on the results of this study, it can be seen that the R-Square results are 0.431 which shows that customer switching intention can be explained by perceptions of Islamic banks (X1) and variety seeking (X2) by $43 \%$, while other variables explain the rest outside of this study.

With the numerator's degree of freedom of 2 and the denominator's degree of freedom of 98, an F-table of 3.09 was found. Based on the results of previous calculations, it can be seen that the hypothesis in this study, Ho is rejected and $\mathrm{Ha}$ is accepted because the F-count is higher than the F-table that is equal to 41.1. Thus it can be seen that the perception of sharia banks and variety-seeking together significantly influences the intention of switching conventional bank customers to Sharia Banks in Bekasi City.

\section{Path Coefficient Results}

The results of hypothesis testing through the path coefficient can be seen in the following table.

Tabel 4 Hasil Koefisien Jalur (Path Coefficient)

\begin{tabular}{|l|r|r|r|r|r|}
\hline & $\begin{array}{c}\text { Original } \\
\text { Sample }\end{array}$ & $\begin{array}{c}\text { Sampel } \\
\text { Mean } \\
(\boldsymbol{M})\end{array}$ & $\begin{array}{c}\text { Standard } \\
\text { Deviation } \\
\text { (STDEV) }\end{array}$ & $\begin{array}{c}\boldsymbol{T} \\
\text { statistic }\end{array}$ & $\begin{array}{c}\boldsymbol{P} \\
\text { Value }\end{array}$ \\
\hline $\mathrm{X} 1$-> Y & 0.625 & 0.654 & 0.089 & 7.017 & 0.000 \\
$\mathrm{X} 2->\mathrm{Y}$ & 0.091 & 0.086 & 0.075 & 1.222 & $\mathbf{0 . 2 2 2}$ \\
\hline
\end{tabular}

Sumber: Data diolah, 2019. 
14 | Estu Banyu Ramadhani, Adril Hakim, Rianti Pratiwi: Effect of Perfection on Sharia Bank and Variety Seeking on Customer Switching Invention From Conventional Banks in Bekasi City

Based on the results of the study in the previous table, the inner model equations can be obtained in this study, namely:

$$
\eta=0,625 \xi_{1}+0,091 \xi_{2}+\zeta_{j}
$$

Information:

$\xi_{1}=$ Perception of Sharia Banks

$\xi_{2}=$ Variety Seeking

$\eta=$ Customer Switching Intention

$\zeta_{\mathrm{j}}=$ Inner residual error

The results show that if the public's perception of Islamic banks is increased by 1 level, then the intention to move customers will increase by 0.625 (assuming the influence of the variety-seeking variable is considered constant or equal to 0 ). However, if variety-seeking is increased by 1 level, the intention to move customers will only increase by 0.091 (assuming the effect of perception variables on Islamic banks is considered constant or equal to 0 ).

To find out the significance level in the partial hypothesis testing at alpha $5 \%$, the path coefficient value indicated by the t-statistic must be above 1.96 for the two-tailed hypothesis and must be above 1.64 for the one-tailed hypothesis. Based on table 4, it can be seen that the hypothesis in this study Ho1 was rejected, and Ha1 was accepted because the t-statistic score of perception of sharia banks towards the intention of moving customers $>1.96$ (above the t-table value) is 7,017. Meanwhile, Ho2 was accepted, and Ha2 was rejected because the varietyseeking t-statistic score for the intention to move customers $<1.96$ (under the $t$ table) was 1,222.

\section{Figure 3 SEM Results}

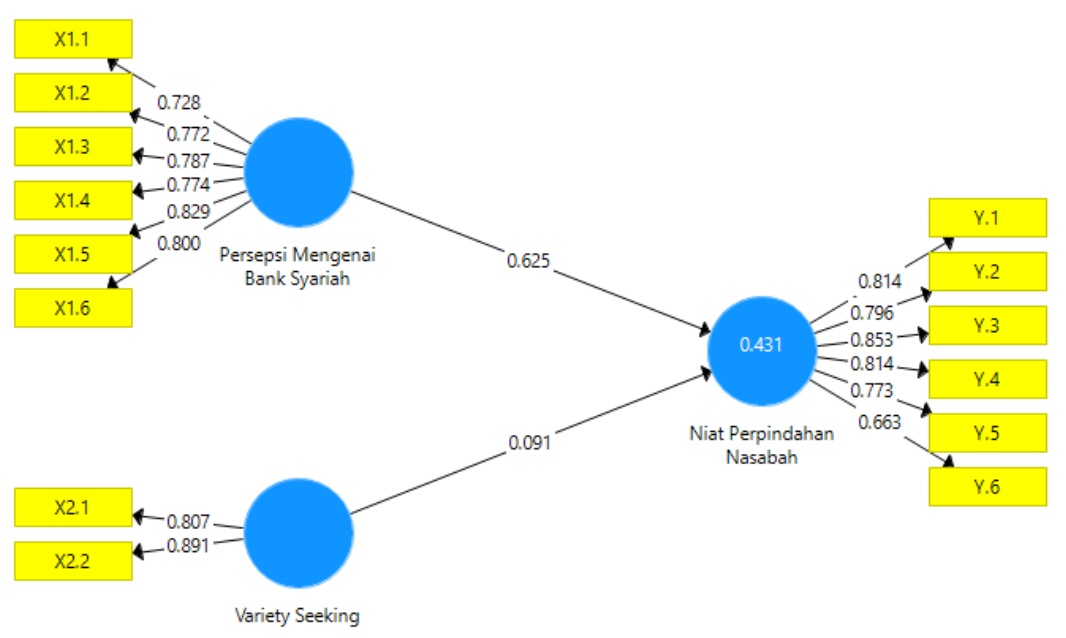

Source: Data processed, 2019. 
Jurnal Ekonomi dan Perbankan Syariah

Vol. 7. No.2, 0ktober 2019: 5-19, ISSN (cet): 2355-1755 | ISSN (online): 2579-6437

\section{5}

The fit model of this study is in Figure 3. Thus, it can be concluded that public perceptions about Islamic banks have a positive and significant effect on the intention of moving conventional bank customers to Islamic banks. In contrast, variety seeking does not have a significant effect on the intention of moving conventional bank customers to the Islamic Bank.

\subsection{Discussion}

Each individual has different characteristics in processing everything. For this reason, the respondents' profiles in the questionnaire helped to find out how the characteristics of the respondents. As in comprehensive research, this study divides respondents by gender, namely women and men. After those respondents are grouped based on their latest education and work to describe the way of thinking of respondents, how respondents understand the information they get. The more knowledge a person has, the more complex the way they think. After that, respondents were asked questions about the bank products they used and the sources of information they obtained about Islamic banks, which helps illustrate the experience of respondents regarding the world of banking. The last respondent is divided based on the ownership of Islamic bank accounts, which illustrates how the respondents directly applied information that the respondents had previously obtained about Islamic banks.

In this study, it was found that perceptions of Islamic banks and varietyseeking jointly influenced the intention of moving conventional bank customers to Islamic banks which can be seen from the results of statistical tests that show that F-count higher than F-table is equal to 41.1.

Based on the results of the path coefficient can be seen that the perception of Islamic banks partially influences the intention of moving customers which can be seen from the t-statistic score of perceptions about Islamic banks towards the intention to move customers $>1.96$ (above the t-table value) which is equal to 7,017. This can also be known from the results of the questionnaire that has been given, which shows that $68 \%$ of respondents have a good perception of Islamic banks. Thus, the results of this study are following research conducted by Jannah \& Widodo (2018), which in his research, the perception of Islamic banks influences the intention of conventional bank customers to switch (switching) to Islamic banks. Also, contrary to the results of research conducted by Suwarsi \& Wulandari (2017) which although the informant's perception of the Islamic bank is good, the informant still maintains the account he has at a conventional bank.

Meanwhile, based on the results of the variety-seeking path coefficient partially does not affect the intention of moving customers. These results can be seen from the t-statistic score of variation seeking the intention to move customers $<1.96$ (under the t-table), which is equal to 1,222 , which shows that this research contradicts previous research in which variety-seeking influenced the intention of moving conventional bank customers to Islamic banks. Like the results of research Najib (2009) in which according to him several factors that 
16 | Estu Banyu Ramadhani, Adril Hakim, Rianti Pratiwi: Effect of Perfection on Sharia Bank and Variety Seeking on Customer Switching Invention From Conventional Banks in Bekasi City

encourage customers to move from conventional banks to Islamic banks or vice versa is because of boredom, and curiosity about other products. Similarly, according to Trijp \& Inman (1996) some characteristics of the level of product categories offered by marketers might determine success in attracting consumers who need variations for alternative brands.

From the results of the analysis of interviews conducted after analyzing the questionnaire data, it can be seen that the first thing respondents saw from Islamic banks was not in terms of products that conventional banks or Islamic banks offered. According to respondents, when compared to Conventional Banks, certainly far superior and better-known products of Conventional Banks compared to Islamic Banks. Also, other reasons are those who want to move to Islamic banks because they want to be free from the bond of usury found in conventional banks, they want to achieve God's blessing and get a blessing on the assets they can. Finally, according to several other respondents, having a variety of seeking behavior is quite tricky because it requires a longer time in the process, which makes variety seeking in this study not have a significant influence on the intention of moving conventional bank customers to Islamic banks.

\section{CONCLUSION}

1) The perception of sharia banks and variety-seeking together has a significant effect on the intention of moving conventional bank customers to sharia banks. This shows that the public perception of Islamic banks and variety-seeking behavior owned by the community together will influence the intention of Muslim communities in Bekasi to switch from conventional banks to Islamic banks.

2) Perception regarding Islamic banks has a positive and significant effect on the intention of moving conventional bank customers to Islamic banks. This shows that the better the perception of the Muslim community in Bekasi regarding sharia banks, the more the community's intention to switch from conventional banks to sharia banks, and vice versa the worse the community's perception of sharia banks, the public will tend to be reluctant to switch from conventional banks to Islamic banks.

3) Variety seeking does not significantly influence the intention of moving conventional bank customers to Islamic banks. This shows that the intention of the Muslim community in Bekasi City to move from conventional banks to Islamic banks is not influenced by the behavior of seeking variations that are usually owned by each individual. 
Jurnal Ekonomi dan Perbankan Syariah

Vol. 7. No.2, 0ktober 2019: 5-19, ISSN (cet): 2355-1755 | ISSN (online): 2579-6437

17

\section{REFERENCES}

Abdillah, W., \& Jogiyanto. (2015). Partial Least Square (PLS): Alternatif Structural Equation Modelling (SEM) dalam Penelitian Bisnis (1st ed.). Yogyakarta: ANDI OFFSET.

Ajzen, I. (1991). The Theory of Planned Behavior. Organizational Behavior And Human Decision Processes, 179-211.

Ajzen, I. (2005a). Attitudes, Personality, and Behavior. Maidenhead, England: Open University Press.

Ajzen, I. (2005b). Behavioral Interventions Based on the Theory of Planned Behavior Behavioral Interventions Based on the Theory of Planned Behavior.

Asnawi, N., \& Fanani, M. A. (2017). Pemasaran Syariah: Teori Filosofi, dan Isu-isu Kontemporer (1st ed.). Depok: Rajawali Pers.

Assael, H. (2001). Consumer Behavior and Marketing Action (6th ed.). New York: Thomson \& Learning.

BPS. (2010). Penduduk Menurut Wilayah dan Agama yang Dianut. Retrieved from https://sp2010.bps.go.id/index.php/site/tabel?tid=321\&wid=0

BPS. (2016). Jumlah Penduduk Menurut Agama Kota Bekasi 2015. Retrieved from https://bekasikota.bps.go.id/statictable/2016/12/20/43/jumlahpenduduk-menurut-agama-.html

BPS. (2019). Kota Bekasi Dalam Angka Bekasi Municipality in Figures 2019.

Gabriella, G., \& Olsson, F. (2012). How do the predictors of switching intention influence switching behavior?

Harianja, F., Zulkarnain, \& Noviasari, H. (2017). Analisis Pengaruh Kualitas Layanan dan Tarif Premi terhadap Kepuasan Nasabah dan Switching Intention Pada PT.Prudential Life Assurance Kota Pekanbaru. JOM Fekon, 4(2).

Hawkins, D., \& Mothersbaugh, D. L. (2016). Consumer Behavior: Building Marketing Strategy. New Jersey: McGraw-Hill Education.

Ibrahim, O., \& Abduh, M. (2013). Customer Satisfaction and Switching Behavior in Saudi Islamic Banks : An Exploratory Study, 2(2), 17-25.

IFCI, I. F. C. I. (2017). Islamic finance country index - ifci 2017, 47-67.

Jannah, A. M., \& Widodo, A. (2018). Pengaruh Persepsi Bank Syariah di Indonesia terhadap Customer Switching Intention dengan Customer Satisfaction sebagai Mediator. Jurnal Sekretaris \& Administrasi Bisnis, II(1), 41-50. Retrieved from http://repository.telkomuniversity.ac.id/pustaka/files/142905/dp/pengaru h-persepsi-bank-syariah-di-indonesia-terhadap-customer-switchingintention-dengan-customer-satisfaction-sebagai-mediator.pdf

Jaya, L. (2016). J Yang Mempengaruhi Customer Switching Behavior Dalam 
18 | Estu Banyu Ramadhani, Adril Hakim, Rianti Pratiwi: Effect of Perfection on Sharia Bank and Variety Seeking on Customer Switching Invention From Conventional Banks in Bekasi City

Industri Retail Banking Pada Bank BCA. Jurnal Bisnis dan Manajemen, 52(11), 115-141.

Ka, A. G., \& Em, A. (2017). Customers ' Switching Intention in Oman 's Banking Industry Business \& Financial Affairs, 6(2). https://doi.org/10.4172/2167-0234.1000270

Keller, K. L. (2013). Strategic Brand Management (4th ed.). Pearson Education.

Kotler, P., \& Keller, K. L. (2012). Marketing Management (14th ed.). Pearson Prentice Hall.

Lewis, M. K., \& Algaoud, L. M. (2001). Perbankan Syariah: Prinsip, Praktik, dan Prospek. PT Serambi Ilmu Semesta.

LPS. (2019). Distribusi Simpanan Bank Umum Periode Januari 2019.

Maholtra, N. K. (2010). Marketing Research (6th ed.). New Jersey: Pearson Education.

Masruroh, R. (1999). Pengaruh Positioning dan Diferensiasi terhadap Brand Switching Perbankan Syariah.

Najib, M. (2009). Analisis Konsumen Berpindah Merek ( BrandSwitcher ) Pada Bank Syariah Dan Bank Konvensional, 4(1), 1-25.

OJK. (n.d.). Sejarah Perbankan Syariah. Retrieved from www.ojk.go.id/id/kanal/syariah/tentang-syariah/pages/Sejarah-

Perbankan-Syariah.aspx

OJK. (2018). Snapshot Perbankan Syariah Indonesia 2018.

OJK. (2019). Statistik Perbankan Syariah Januari 2019.

Peter, J. P., \& Olson, J. C. (2010). Consumer Behavior \& Marketing (9th ed.). New York: McGraw-Hill Education.

Rama, A. (2017). An Exploration of Customers' Switching Behavior in Islamic Banking Industry. Journal of Islamic Monetary Economics and Finance, 2(2).

Sangadji, E. M., \& Sopiah. (2013). Perilaku Konsumen Pendekatan Praktis disertai: Himpunan Jurnal Penelitian. Yogyakarta: CV ANDI OFFSET.

Sanusi, A. (2011). Metodologi Penelitian Bisnis. (D. A. Halim, Ed.) (Pertama). Jakarta Selatan: Salemba Empat.

Schiffman, L. G., Kanuk, L. L., \& Hansen, H. (2012). Consumer Behaviour: A European Outlook (2nd ed.). New Jersey: FT Prentice Hall.

Schiffman, L. G., \& Wisenblit, J. L. (2015). Consumer Behavior Consumer Behavior (11th ed.). United States: Pearson Education.

Setiadi, N. J. (2003). Perilaku Konsumen: Konsep dan Implikasi untuk Strategi dan Penelitian Pemasaran (1st ed.). Jakarta: PRENADAMEDIA GROUP.

Simamora, B. (2018). Teknik Sampling. Retrieved January 30, 2019, from www.bilsonsimamora.com

Sugiyono. (2016). Metode Penelitian Kombinasi (Mixed Methods). (M. T. 
Jurnal Ekonomi dan Perbankan Syariah

Vol. 7. No.2, 0ktober 2019: 5-19, ISSN (cet): 2355-1755 | ISSN (online): 2579-6437

19

Sutopo, Ed.). Bandung: ALFABEA, cv.

Sumarwan, U. (2011). Perilaku Konsumen Teori dan Penerapannya dalam Pemasaran. Bogor: Ghalia Indonesia.

Sutanto, H., \& Umam, K. (2013). Manajemen Pemasaran Bank Syariah. Bandung: CV Pustaka Setia.

Suwarsi, A., \& Wulandari, N. (2017). Identifikasi Potensi Nasabah Baru Bank Syariah Ditinjau dari Customer Switching Intention. Jurnal Ekonomi Dan Bisnis Islam, 3(2). Retrieved from https://ejournal.unair.ac.id/JEBIS/article/view/6808

Trijp, H. C. M. Van, \& Inman, J. J. (1996). Why Switch ? Product CategoryLevel Explanations for True Variety-Seeking Behavior, (May 2015). https://doi.org/10.2307/3152125

Vyas, V., \& Raitani, S. (2014). Drivers of Customers' Switching Behaviour in Indian Banking Industry. International Journal of Bank Marketing, 32(4), 321-342.

Yusuf, A. M. (2017). Metode Penelitian: Kuantitatif, Kualitatif, Penelitian Gabungan (1st ed.). Jakarta: PRENADAMEDIA GROUP.

Zainal, V. R., Djaelani, F., Basalamah, S., Yusran, H. L., \& Veithzal, A. P. (2017). Islamic Marketing Management. (Y. N. I. Sari, Ed.). Jakarta: Bumi Aksara.

Zhang, D. (2009). Customer Switching Behaviour in the Chinese Retail Banking Industry A thesis submitted in partial fulfilment of the requirements for the Degree of Master of Commerce and Management at Dongmei Zhang Customer Switching Behaviour in the Chinese Retail Bankin. 